\title{
Lärarens arbete mot utveckling av generiska färdigheter och variation i teknikvetenskaplig utbildning genom relationsskapande åtgärder
}

\author{
Jennifer Leijon* och Cecilia Boström \\ Avdelningen för elektricitetslära, Institutionen för teknikvetenskaper, Uppsala universitet
}

\begin{abstract}
För att upprätthålla en god pedagogisk nivå inom vissa utbildningsområden av teknikvetenskaper krävs steg mot förändring och nytänkande. Ett av de generella problemen inom teknikvetenskaper är behovet av att utbilda ingenjörer som även har generiska eller mjuka färdigheter för att möta dagens samhällsutmaningar, men att ingenjörsundervisning i stort främst odlar studenternas hårda färdigheter. I denna text diskuteras hur universitetslärare inom ingenjörsområden kan reflektera kring utveckling av generiska färdigheter med små medel och utifrån tankar kring mellanmänskligt relationsskapande. För att beskriva hur förändringsarbetet kan se ut genomförs en fallstudie av räknelektioner under kursen Kraftelektronik, 5 hp, som ges på avancerad nivå vid Uppsala universitet. Efter förändringsarbetet var en högre andel studenter ganska eller mycket nöjda med kraftelektronikkursen, och fler blev även godkända vid ordinarie tentamen än året innan. Dock uppfattade vissa studenter de nya lektionerna som sämre och mer ostrukturerade än andra lektioner. Materialet är indelat i olika kategorier som kan kopplas till övriga mellanmänskliga relationer och mjuka värden för att kontrastera mot en bild av hårda matematik- eller teknikstudier och för att inspirera till ett verkligt förändringsarbete.
\end{abstract}

Nyckelord: Generiska färdigheter, kraftelektronik, relationsskapande process, mjuka värden

\section{INTRODUKTION}

Uppsala universitet har rekommendationer och riktlinjer för det ansvar som kan ställas på universitetet och studenterna i samband med undervisning för att nå en god pedagogisk utveckling och verksamhet. Sådana riktlinjer finns även vid de flesta andra lärosäten. Skriften Pedagogiskt program för Uppsala universitet tydliggör att universitetet ska verka för studentaktiverande och varierande undervisningssätt, med möjligheter till samarbete, diskussioner och reflektion (2008; 20I8).

Ingenjörsutbildningarna får ofta kritik att undervisningen utförs på samma sätt som för femtio år sedan. En stor del av undervisningen utgörs av föreläsningar där föreläsaren förmedlar kunskap till studenterna och kompletterande lektionstillfällen. Lektioner med räkneuppgifter som genomförs under universitetskurser inom fysik, teknik och matematik är ofta likformigt och statiskt utformade och bygger på att läraren löser tal rakt av på tavlan som studenterna förväntas skriva av och förstå inför slutlig tentamen - alltså med mycket liten del variation och aktiverande moment, där studenterna inte heller uppmuntras till att samarbeta eller diskutera, varken med varandra eller med läraren. Många studenter är så pass vana vid denna typ av matematik- och fysikundervisning att även små steg ifrån detta ifrågasätts; svårigheten att acceptera förändringar i lärosalen diskuteras exempelvis av Andersson et al. (2004). Dessutom anser vissa lärare, som ofta bedriver forskning parallellt med undervisningen, att de inte har tillräcklig tid,

*Författarkontakt: jennifer.leijon@angstrom.uu.se

Artiklar och reflektioner är kollegialt granskade. Övriga bidragstyper granskas av redaktionen. Se www.hogreutbildning.se ISSN 2000-7558

(C)2019 Jennifer Leijon och Cecilia Boström. This is an Open Access article distributed under the terms of the Creative Commons Attribution-NonCommercial 4.0 International License (https://creativecommons.org/licenses/by-nc/4.0/), allowing third parties to share their work (copy, distribute, transmit) and to adapt it, under the condition that the authors are given credit, that the work is not used for commercial purposes, and that in the event of reuse or distribution, the terms of this license are made clear.

Citation: Jennifer Leijon och Cecilia Boström (2019) «Lärarens arbete mot utveckling av generiska färdigheter och variation i teknikvetenskaplig utbildning genom relationsskapande åtgärder», Högre utbildning, 9(1), 85-97. http://dx.doi.org/10.23865/hu.v9.1452 
tillräckliga resurser eller lust för att undervisa; det undersöks exempelvis av Palali et al. (2018) samt Burke-Smalley et al. (20I7). Framförallt har de kunskaps- och färdighetskrav som ställs på en ingenjör idag förändrats (Felgueiras et al., 2017) och pedagogisk forskning har visat att de mer traditionella undervisningssätten många gånger inte är de bästa för att uppnå önskat resultat (Felder et al., 2000).

Några explicita utmaningar som den mer traditionella ingenjörsundervisningen ställs inför är att skapa utrymme för att diskutera ekonomisk, social och miljömässig hållbarhet, att ge studenterna chans till gränsöverskridande samarbete, att öva muntlig presentation och att överlag bidra till ett medvetet etiskt förhållningssätt. Färdigheter kan delas upp i hårda (hard skills) och mjuka (soft skills), där de hårda färdigheterna exempelvis handlar om tekniskt kunnande medan de mjuka färdigheterna inkluderar den egna personligheten och hur man hanterar andra människor. De mjuka färdigheterna kallas ibland även generiska färdigheter, och hur de inkluderas i den högre utbildningen har nyligen diskuterats i en översiktsartikel (Chan et al., 2017). Värdet av generiska färdigheter i undervisningssituationer diskuterades även nyligen av Tang (20I8). Begreppet 2Ist Century skills används även för dessa färdigheter (van Laar et al., 20I7), vilket påvisar att dagens samhälle kräver detta i högre grad än tidigare.

De kurser som ges inom teknikvetenskaper ingår ofta i ett yrkesprogram, vanligen inom civilingenjörs- eller högskoleingenjörsprogrammet. Traditionellt har det tekniska kunnandet och expertisen inom ett visst område varit de mest centrala målen för att examinera attraktiva ingenjörer till arbetsmarknaden; dessa färdighetsmål kan ses som hårda (Robles, 20I2), medan färdigheter inom kommunikation, flexibilitet, attityd och teamwork kan ses som mjuka eller generiska. Med nya samhällsutmaningar är det därför centralt att studenterna även tränar på de generiska färdigheterna under en yrkesutbildning. Felder et al. beskriver hur man kan uppnå fler eller andra mål inom en utbildning genom att ändra på sin undervisning (2000). Robels undersöker vilka som är de tio viktigaste generiska färdigheterna för företagare: kommunikation, integritet, artighet, ansvarstagande, positiv attityd, sociala färdigheter, professionalitet, flexibilitet, arbetsmoral och gruppkänsla (20I2). I en annan studie identifieras ett glapp mellan det som kan krävas av en ingenjör $i$ industrin och det som lärs ut inom ingenjörsutbildningen där brister specifikt inom problemlösning, kommunikation, ledarskap och etik identifierades hos studenterna (Nair et al., 2009). Det visar sig även att mjuka färdigheter har stort inflytande på en persons ekonomi och sociala liv (Heckman \& Kautz, 20I2).

I studien av Strobel et al. undersöks till vilken grad omtanke och empati kan kopplas till ingenjörsyrket; de kommer fram till att tekniska mål mot exempelvis ökad hållbarhet till stor del utgår från dessa egenskaper, men att ingenjörer och ingenjörsutbildningen inte fokuserar nog på detta (2013). Det understryks även att arbetet mot ett mer hållbart samhälle kräver tvärvetenskapligt arbete i ingenjörsutbildningen och att det nås genom ett intresse och en öppenhet för andra forskningsområden (Tejedor et al., 20I8). Att utbildningen av ingenjörer måste ändras för att öka studenternas kreativa sidor har även diskuterats (Catarino et al., 20I7). En liknande analys om förändring mot mer fokus på dessa värden förs av Boyce et al. för utbildningar inom redovisning, där det föreslås att inkludera verklighetstrogna case i utbildningen (200I). Prince diskuterar att aktiva inlärningsformer och studiemiljöer som främjar till grupparbete och samarbete i många fall har en positiv inverkan på studenternas lärande (2004). Den pedagogiska forskningen lyfter även fram vikten av att ha ett problembaserat lärande (PBL) inom ingenjörsutbildningarna och hur detta kan främja studenternas förmåga att tänka kreativt (design thinking) (Clive et al., 2005). Det finns alltså många författare som uppmuntrar till pedagogisk utveckling mot mer generiska färdigheter och variation i den högre utbildningen. Sammantaget krävs en förändring av det traditionella kursupplägget inom teknikvetenskaper för att upprätthålla universitetets riktlinjer och för att förbereda studenterna för framtida arbetssituationer. 


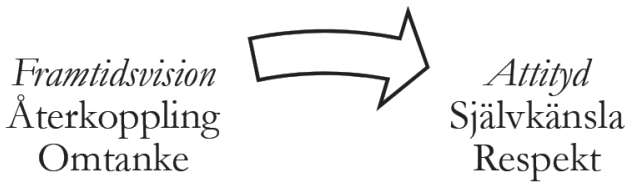

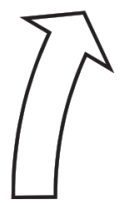

Delaktighet

Aktivitet

Kreativitet

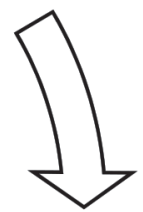

Förväntning

Målsättning Erfarenhet

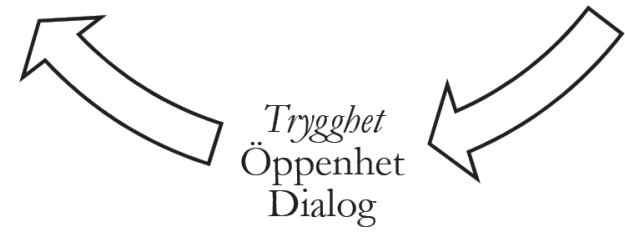

Figur I. För att variera bilden av teknikvetenskaper diskuteras lärande inom detta omräde utifrån relationsskapande ord såsom Förväntning, Trygghet och Framtidsvision.

Denna text reflekterar över hur läraren kan arbeta med generiska färdigheter och variation som en del av teknikvetenskaplig undervisning med hjälp av relationsskapande processer. Dess syfte är att inspirera till förändring hos lärare inom teknikvetenskaplig undervisning för att ta steg mot utveckling av studenternas generiska färdigheter. Speciellt utgör räknelektioner i kursen Kraftelektronik, ${ }^{1} 5 \mathrm{hp}$, vid Uppsala universitet en fallstudie för att visa på hur förändringsarbetet kan planeras inför en konkret undervisningssituation, samt hur detta påverkar studenternas slutliga resultat och helhetsbild av kursen. Kraftelektronikundervisning är traditionellt tekniskt tungt där traditionella föreläsningar, räknelektioner, laborationer och simuleringar varvas inför en slutlig skriven salstenta. Undervisningen sker vanligen utan större utrymme för variation eller övning av generiska färdigheter.

Textens disposition är följande: $\mathrm{i}$ avsnitt 2 ges en beskrivning av den pedagogiska idén där relationsskapande ord bygger upp materialet. I avsnitt 3 beskrivs hur den pedagogiska idén implementerades i kursen Kraftelektronik. I avsnitt 4 beskrivs resultatet efter kursens och kursutvecklingens genomförande. I avsnitt 5 diskuteras arbetet med en reflektion över dess utfall och i avsnitt 6 dras några slutsatser.

\section{PEDAGOGISK IDÉ}

Förändringsarbetet för att arbeta mer med generiska färdigheter inom ingenjörsvetenskaper kan genomföras utifrån de relationsskapande och mjuka värdena i Figur I, skapad av författarna. De kategorier vilka materialet delas in i är Attityd, Förväntning, Trygghet, Delaktighet och Framtidsvision; denna process är framtagen av författarna själva. För att ytterligare påvisa de känslomässiga ordens möjliga betydelse för undervisning inom teknikvetenskaper har författarna valt att

1 http://www.uu.se/utbildning/utbildningar/selma/kursplan/?kKod=1TE046 [Hämtningsdatum: 201906-11] 
lägga till fler ord inom respektive kategori, såsom Omtanke och Öppenhet. Alla dessa ord kan vara intressanta att fundera kring och inkludera när man vill skapa en mer långvarig relation till en annan person - eller skapa djupinlärning och främja livslångt lärande. Kategorierna går på flera sätt in i varandra och hand $\mathrm{i}$ hand, vilket kan bli en positiv utvecklingsspiral för studenter och lärare om arbetet utförs med respekt och omtanke - precis som i alla relationer.

Att öppna för diskussioner kring matematik och teknik ur en relationsskapande process är ett försök till en annorlunda vinkling av problemet med undervisningen inom teknikvetenskaper för att inspirera till förändringsarbete. Processen kan användas som en grund för reflektion kring generiska färdigheter i teknikundervisning och för att bidra till en helhetssyn av varje student.

\subsection{Attityd, självkänsla och respekt}

Att som lärare ha ett välfungerande förhållande till studenter och kollegor är viktigt. Uppsala universitets riktlinjer avseende studenternas studievillkor (20IO) beskriver att förhållandet lärare-student ska utgöras av ömsesidig respekt. Läraren bör fundera över sin personliga attityd till undervisningssituationen och lärandet och försöka identifiera sin egen kunskapssyn, exempelvis vid utformandet av en pedagogisk meritportfölj. ${ }^{2}$

En viktig framgångsfaktor för lärande är att ha en positiv inställning till detta. Studenter som har ett positivt synsätt på fysik visar sig lyckas bättre inom området än de som har en negativ bild av fysik (Veloo et al., 20I5). En lärare som går in med en negativ bild av undervisandet, exempelvis som något betungande som bara tar tid från forskningen, kanske inte kan förvänta sig att studenterna ska gå in med en positiv syn på teknik-, fysik- eller matematikämnet; detta kan bli till en självuppfyllande profetia där studenterna ses som okunniga och samtidigt presterar dåligt av ointresse. Att lärarens och studenternas engagemang hänger samman diskuteras exempelvis i boken Universitetspedagogik (Elmgren \& Henriksson, 20I6) och forskning visar att passionerade lärare kan hjälpa studenterna till högre betyg (Ruiz-Alfonso \& León, 20I7). Erfarenheter och forskning tyder på att många unga människor i Sverige ser matematik som något krångligt och kanske rentav tråkigt. Vissa studenter upplever stark osäkerhet inför matematik (math anxiety) (Schillinger et al., 20I8) och att denna rädsla kan påverka akademiska resultat inom området (Wahid et al., 20I4). I boken Learning to love math (Willis, 20Io) beskrivs olika tillvägagångssätt som läraren kan använda sig av för att minska den oro och stress som studenter kan känna inför matematik och för att förändra bilden av något ointressant och svårt till något som de är mer bekväma med och uppskattar.

Både studenter och lärare kan alltså ha stor behållning av metakognitiva tankeprocesser kring lärande. Studenternas självkänsla och förmåga att skatta sin egen prestation inom fysikområdet är ofta kopplat till hur väl studenterna presterar akademiskt inom dessa discipliner (Tezer et al., 20I5) och läraren kan anses ha en viktig roll i att ge studenterna ett gott intryck av sin egen person kopplad till studierna inom fysik, teknik och matematik för att uppnå goda studieresultat. Som lärare kan man uppmuntra studenterna till metakognition genom att möjligen visa olika värderingstest för studenterna eller genom att inkludera små diskussioner i klassrummet om lärandet: exempelvis diskutera hur man kan hantera den stress som kan uppstå i en examinationssituation eller hur man kan strukturera upp sina studier för att hinna med studiebördan.

\subsection{Förväntning, målsättning och erfarenhet}

Både lärare och studenter har en mer eller mindre tydlig bild av vad studierna ska leda fram till och förväntningar på sitt eget och andras agerande i lärandesituationen. Ju mer samstämmig den bilden är, desto större chans att båda parter blir nöjda med kursens utfall. Innan läraren ska ta

2 https://mp.uu.se/web/info/undervisa/pedagogisk-utveckling/pedagogisk-meritering [Hämtningsdatum: 2019-06-11] 
sig an en ny kurs är det viktigt att gå igenom förra årets summativa kursvärderingar från studenter och genomföra eventuella nödvändiga förändringar i enlighet med det som framkommit i dessa, samt tillse att studenterna får insyn i detta (Uppsala universitet, 2008). Dessutom ska läraren se över kursmålen och se till att de stämmer överens med det som faktiskt undervisas och examineras under kursen samt att tydliggöra kursmål för studenterna, när och hur olika mål ska uppfyllas och vilka hjälpmedel som studenterna har att tillgå samt vad som kan anses som fusk (Uppsala universitet, 2008). De övergripande mål som ställs på högskolekurser på grundnivå respektive avancerad nivå återfinns i högskolelagen och ska tas i beaktande. För att undersöka vilken nivå de stipulerade kursmålen ligger på kan exempelvis Blooms taxonomi användas eller någon taxonomi som är särskilt anpassad för teknikvetenskaper (Elmgren \& Henriksson, 20I6).

\subsection{Trygghet, öppenhet och dialog}

För en god miljö för studenter och anställda ska alla mötas på ett respektfullt sätt och kunna arbeta på lika villkor, i enlighet med exempelvis Handlingsplan för likabehandling av studenter 2014 (Uppsala universitet, 20I4). Det finns stöd att få och man har vissa rättigheter om man som student exempelvis inte känner sig trygg eller har en funktionsnedsättning. Språkverkstaden ${ }^{3}$ och Lässtudio ${ }^{4}$ vid Uppsala universitet är goda tips till studenter, och liknande stödfunktioner återfinns även vid andra lärosäten.

Att skapa en trygg och öppen miljö i klassrummet är mycket viktigt och kan göras på flera olika sätt. Att möblera om i lärosalen för att främja dialog mellan studenter ligger i linje med universitetets pedagogiska mål, där samarbete ska uppmuntras. Man kan exempelvis flytta bord som vanligtvis står i rader mot den svarta tavlan till mindre öar för att gruppera studenterna, detta alltså även om det är matematikuppgifter som ska lösas (Hubbard, 199I). Studenterna kan delas in i mindre grupper i lektionssalen, lära känna nya vänner och få gruppuppgifter att lösa tillsammans. Forskning för att främja samarbete och minska konkurrens mellan studenter inom fysikområdet genomförs; exempelvis undersöks hur studenterna reagerar då de får samma betyg inom en hel studentgrupp baserat på hur en enskild slumpvis vald gruppmedlem presterar under ett laborativt moment som vanligen betygsätts individuellt (Leung et al., 2017).

Att skapa trygghet för studenterna i deras lärandesituation pågår även utanför själva lektionssalen. Om alla studenter får möjlighet att ta del av relevant information och får chans att förbereda sig innan lektioner eller föreläsningar, med hjälp av kursmaterial och information, gärna i elektronisk form, så kan det öka chanserna för att fler studenter vågar prata och känner sig insatta och bekväma i själva lektionssalen och att de är trygga och fria i att de kan genomföra uppgifter hemifrån om det skulle behövas. I enlighet med de riktlinjer som utgivits vid Uppsala universitet bör läraren arbeta för att lämna ut elektroniska informationsresurser (Uppsala universitet, 20IO), vilket kan vara en tidskrävande del av undervisningen som läraren bör ha i åtanke. Att använda de nätbaserade lärplattformarna som universitetet föreslår, såsom Studentportalen, ${ }^{5}$ är mycket lämpligt - de har ofta många funktioner som kan utveckla kreativitet och inkludera studenter aktivt.

\subsection{Delaktighet, aktivitet och kreativitet}

Att ge utrymme för att studenterna ska få vara delaktiga är otroligt viktigt i lärandeprocessen och något som vi inom teknikvetenskaperna bör fokusera mot. Många konkreta exempel på hur man kan genomföra studentaktiverande formativa utvärderingar med studenter återfinns i

3 http://www.sprakverkstaden.uu.se/ [Hämtningsdatum: 2019-06-11]

4 https://ub.uu.se/anvand-biblioteket/for-dig-med-lasnedsattning/\#anchor-300595 [Hämtningsdatum: 2019-06-11]

5 https://studentportalen.uu.se/ [Hämtningsdatum: 2019-06-11] 
boken Classroom assessment techniques (Angelo \& Cross, 1993). Att öka studenternas inflytande på undervisningssituationen är något som arbetas aktivt med på Uppsala universitet och mycket inspiration finns att tillgå. ${ }^{6}$ En av de roliga utmaningarna för läraren i lektionssalen är att själv få stort kreativt utrymme i förhållande till de givna målsättningarna och ramarna och tillsammans med studenterna. Forskare och författare har kommit med många förslag på hur exempelvis matematikundervisningen kan bli mer kreativ (Hubbard, 199I). Att skapa kreativa och studentaktiverande moment under lektionerna kan bland annat göras genom formativa utvärderingar med så kallade klickers. ${ }^{7}$ Att aktivera studenterna mer inom olika ingenjörsutbildningar belyses nyligen i flera forskningsartiklar, exempelvis ges förslag på att aktivera studenterna genom att arbeta med entreprenörskap (Fernandes et al., 20I7), samarbeta med mellanstadieskolor (Fogg-Rogers et al., 20I7) eller ha en forskningsanknytning i undervisningen (Wallin et al., 20I7).

\subsection{Framtidsvision, àterkoppling och omtanke}

Att koppla undervisningen till framtida möjliga arbetssituationer uppmuntrar studenter i sina studier. Man kan exempelvis genomföra studiebesök ute på någon arbetsplats, bjuda in en ingenjör eller forskare som arbetar med just det som lektionen handlar om eller bara diskutera verklighetstrogna situationer kopplat till teorin; detta bör inte vara svårt att genomföra inom ingenjörsvetenskaperna. Inom exempelvis case-metodiken och det problembaserade lärandet används gärna realistiska fallbeskrivningar i undervisningssalen, vilket kan tjäna som inspiration.

Under de examinerande momenten får studenterna återkoppling på huruvida deras kunskapsnivå motsvarade kursens mål. Om studenterna har fått kontinuerlig återkoppling under kursens gång slipper de kanske en viss förvåning över vilket slutbetyg de får. Dock är det vanligt att såväl studenter som lärare inom tekniska ämnen blir förvånade över examensresultaten. I avhandlingen Developing requisite motivation in engineering studies diskuterar Kjell Staffas bland annat hur han som universitetslärare genomfört välplanerade försök att införa studentaktiverande moment men ändå upplevt att många ingenjörsstudenter inte tillgodogjort sig tillräckliga kunskaper för att bli godkända på kurserna (Staffas, 20I6). Han diskuterar därför huruvida läraren kan arbeta för att identifiera vilka studenter som riskerar att bli underkända och hjälpa dessa extra. Staffas problematiserar kring den höga andelen icke-godkända resultat inom ingenjörsvetenskaperna och noterar att vissa studenter konsekvent blir underkända i flera olika kurser, och att den negativa spiralen är något som bör brytas.

\section{FALLSTUDIE, KRAFTELEKTRONIK}

För att skapa en bättre balans i undervisningen användes processen som presenteras i Figur I i planeringsarbetet av räknelektionerna i kursen Kraftelektronik. Vidare beskrivs i detta avsnitt (avsnitt 3.I-3.5) hur de pedagogiska idéerna, presenterade utifrån Figur I, implementerades under 2017 i kursen Kraftelektronik, 5 hp, vid Uppsala universitet, framförallt utifrån lektionsledarens/lärarens personliga synvinkel och reflektion.

Kraftelektronik (eng. power electronics) handlar om elektriska kretsar som byggs upp av olika komponenter såsom dioder, kondensatorer och transistorer och som används i dagens samhälle inom exempelvis mobiltelefoni, transmissionsnät och elbilsbranschen. Kursen som ges

6 http://www.uu.se/asp/ [Hämtningsdatum: 2019-06-11]

7 http://www.polacksbacken.uu.se/Service/utrustning/klickers/ [Hämtningsdatum: 2019-06-11] 
vid Uppsala universitet beskrivs översiktligt genom dess kursplan. ${ }^{8,9}$ Kursen består av föreläsningar, laborationer, simuleringar och räknelektioner samt en slutlig salstenta. Lektionsmaterialet som kopplat till de övriga kursmomenten innehåller beräkningar och kretsanalyser för att skapa förståelse för vanliga kraftelektroniksystem, exempelvis för lik- och växelriktning eller pulsbreddsmodulering. Räkneuppgifterna har olika svårighetsgrader, och oftast löses någon gammal tentauppgift vid varje lektion. För att ge insyn i kursen och den typ av uppgifter som löstes under lektionerna följer två frågor från 2016 års tentamen i Kraftelektronik (observera att även beskrivande text, andra delfrågor och kretsdiagram var del av tentamensfrågorna). En delfråga var: "Draw the circuit symbols for a power-MOSFET and an IGBT. Sketch the junction structure for one of the two devices and label all terminals." En annan delfråga var: "Determine the amplitudes of the Fourier series terms for the load current."

Sammanfattningsvis kan kursen beskrivas som mycket tekniktung och med tonvikt på utveckling av studenternas hårda färdigheter. 2016 års summativa kursvärderingar och höga andel underkända studenter motiverade förnyelsearbetet. Syftet med arbetet var alltså att som lärare utveckla och reflektera kring lektionerna i linje med universitetets riktlinjer och tillgänglig pedagogisk forskning utifrån en egen bild om relationsskapande processer. Den möjligen optimistiska hypotesen från läraren var att detta arbete kunde leda till att många studenter skulle bli nöjda med kraftelektronikkursen som helhet, och slutligen att fler studenter skulle bli godkända vid ordinarie tentamen, vilket undersöktes främst med kvantitativ metod i jämförelse med kurstillfället året innan.

\subsection{Attityd}

Attityden hos lektionsledaren var positiv och med en hög målsättning för att studenterna skulle aktiveras, nå djupinlärning och utveckla generiska färdigheter. Samtidigt fanns det en nervositet $i$ att vara helt ny som lektionsledare i kursen Kraftelektronik. En pedagogisk meritportfölj utformades med egna tankar om värdet av undervisning. Under lektionernas pauser småpratade vi om hur studenternas arbetsbörda som helhet såg ut, delvis för att få studenterna att tänka själva kring eget studieupplägg. Mycket tid avsattes för undervisningen för att den inte skulle krocka med forskningsrelaterade arbeten eller bli till en negativ stress.

\subsection{Förväntning}

Kursen som ges på avancerad nivå har åtta kursmål vilka analyseras utefter innehåll samt svårighetsgrad med hjälp av Blooms taxonomi (Elmgren \& Henriksson, 2016). Några av kursmålen som innehåller beskrivningar av att studenten ska kunna förklara, redogöra för eller beskriva olika delar av kursinnehållet kan anses tillhöra en lägre nivå av lärandeprocessen. Dessutom återfinns flera ord som påvisar att lärandeprocessen även ska ske på en högre nivå enligt Blooms taxonomi, med ord såsom att studenten förväntas konstruera, analysera och simulera under kursens gång. Utifrån kursmålen kan sägas att höga krav ställs på studenten och att de åtta kursmålen bör vara av varierande svårighetsgrad - vissa är enkla ur ett lärandeperspektiv medan andra är mer avancerade.

Kursvärderingarna från kursen given 2016, som därefter sammanställts till en kursrapport av examinatorn, tyder på att studenterna var positiva till kursens helhet. Tyvärr blev hela $63 \%$ underkända vid slutexamen. De kommentarer som direkt relaterar till kursens räknelektioner

8 http://www.uu.se/utbildning/utbildningar/selma/kursplan/?kKod=1TE046 [Hämtningsdatum: 201906-11]

9 http://www.uu.se/utbildning/utbildningar/selma/kursplan/?kpid=34641\&type=1 [Hämtningsdatum: 2019-06-11] 


\section{Jennifer Leijon och Cecilia Boström}

beskriver att det var ett bra tempo och lagom svårighetsgrad på undervisningen, dock fanns inte allt material att tillgå elektroniskt och studenterna önskade fler lektionstillfällen med fler övningsuppgifter. Vissa studentgrupper hade svårigheter med begrepp som borde ha varit kända sedan tidigare kurser i utbildningen. I enlighet med de kommentarer som framkommit i kursvärderingarna planerades därför att inför 2017 exempelvis utöka lektionsantalet från fyra till sex tillfällen, skapa ett självtest via lärandeplattformen Studentportalen med viktiga tröskelbegrepp inför kursstart, behålla en hög nivå och gott tempo samt tillse att lektionsmaterial finns elektroniskt i större utsträckning. Målet var att fler studenter skulle klara sluttentamen i Kraftelektronik under 2017.

\subsection{Trygghet}

Inför kursen skapades ett test om tio frågor på Studentportalen med några av kursens så kallade tröskelbegrepp som studenterna möter redan i kurslitteraturens första kapitel (Hart, 20II). Frågorna är av öppen karaktär, såsom What is a rectifier? Och What characterizes a switch?, som de egentligen inte behöver den specifika kurslitteraturen för att lösa, utan som de kan besvara efter en internetsökning. Testet gjordes för att ge trygghet och förkunskaper även till de studenter som kanske haft svårigheter med tidigare kurser och skapa en gemensam grund att arbeta vidare på.

\subsection{Delaktighet}

För att öka kreativiteten, studentaktiviteten och undervisningens variation bokas den laborativa lärosalen på Blåsenhus ${ }^{10}$ för ett av lektionstillfällena, trots att kursen normalt ges på Ångströmlaboratoriet. I den laborativa lärosalen finns stor möjlighet för studenterna att arbeta kreativt med smartboards, datorer och öppna lärandemiljöer. Det kan vara en bra idé att undersöka vilka andra salar som finns att tillgå på universitetet, särskilt om man känner sig missnöjd med sådant som ventilation, teknik, möblemang, ljus osv. i de lokaler som man vanligtvis blir tilldelad. För att återkoppla till studenternas bild av lektioner och föreläsningar genomförs en formativ utvärdering ungefär i mitten av kursen, där studenterna snabbt ombeds skriva ner vad som varit otydligast under den aktuella lektionen och under kursen som helhet hittills; därefter görs mindre förändringar i kursupplägget för att möta studenternas frågor.

\subsection{Framtidsvision}

Erfarenheten från kursen i Kraftelektronik är att 2016 blev hela $63 \%$ av studenterna ickegodkända. De dåvarande lärarna var mycket missnöjda med utfallet, trots att studenternas allmänna bild av kursen och dess lärare var positiv. Kursutvärderingen 2016 besvarades av $51 \%$ av deltagarna, varav $75 \%$ var ganska eller mycket nöjda med kursen. Att blicka framåt och hoppas på att nästa års tentamensutfall ska bli bättre kan kännas tungt, men med små förändringar av kursupplägget och med en god attityd hoppades vi kunna hjälpa fler studenter att klara tentamen och ge dem hopp om framtiden som ingenjörer.

\section{RESULTATET FRÅN KURSUTVECKLINGEN AV KRAFTELEKTRONIK, 20 I 7}

Efter att kursen Kraftelektronik genomfördes 2017 med försök till förändringsarbete utifrån en relationsskapande process analyserades kursvärderingarna och tentamensresultatet. Det kan

10 http://www.uu.se/om-uu/kvalitetsarbete/larande/e-larande/laborativ-larosal[Hämtningsdatum:201906-11] 
sägas att några studenter verkade mer nöjda med tidigare mer traditionella lektionsupplägg och att vissa uppfattade de nya lektionerna som ostrukturerade. Att omorganisera borden i klassrummet för att uppmuntra till samarbete gjorde exempelvis lektionen mer rörig. Dock var besöket i den laborativa lärosalen ett uppskattat inslag och den information som lärarna fick ut av de formativa kursutvärderingarna var till god hjälp i kursutvecklingen. Den formativa utvärderingen bestod av att studenterna fick skriva ner de mest oklara delarna av en särskild lektion vid slutet av denna, och dessutom de mest oklara delarna med kursen som helhet dittills. De skrivna svaren sammanställdes, analyserades och ledde till konkreta förändringar (förbättringar) i lektionssalen och mer övergripande förslag kring kursen som helhet; utfallet diskuterades inom lärargruppen. Vid den slutliga summativa kursvärderingen, som besvarades av $59 \%$ av kursdeltagarna, var $90 \%$ ganska eller väldigt nöjda med kursen 2017 (vilket kan jämföras med 5I \% svarande där 75 \% var ganska eller mycket nöjda med kursen given 2016). Övriga lärare vid kursen var mycket positiva och stöttande vid införandet av små förändringar under lektionsupplägget. Som ensam lektionsledare var det förhållandevis enkelt att implementera förändringar vid lektionerna som inte störde andra delar av kursen (såsom labbar och föreläsningar). Upplevelsen var att övriga lärare blev nyfikna på utvecklingen och ville bli en del av det; exempelvis kom resterande lärare frivilligt till lektionen i den laborativa lärosalen. Övriga lärare var även positiva till feedbacken från studenterna vid den formativa kursvärderingen.

Trots att några studenter upplevde lektionsupplägget som rörigt, blev en större andel studenter godkända vid sluttentamen detta år än tidigare, från $63 \%$ underkända studenter till $46 \%$ underkända studenter vid ordinarie tentamenstillfälle. Anledningen till att fler studenter blev godkända och kände sig nöjda med kursen detta år kan bero på olika saker, men mer studentaktiverande och varierande undervisning, där mellanmänskliga relationer stärks, bör leda till att fler klarar kurserna inom teknikvetenskaper. I arbetet försökte vi ta vara på tidigare års kursvärderingar, med resultatet att exempelvis antalet lektioner utökades och att vissa tröskelbegrepp reddes ut tidigt i kursen. Andelen underkända studenter (46\%) är fortfarande så pass hög att ett fortsatt utvecklingsarbete med denna och andra kurser inom ingenjörsutbildningarna är mycket motiverat och angeläget.

\section{DISKUSSION OCH REFLEKTION}

Förändringsarbete inom ingenjörsutbildningarna kan bestå av små insatser vid enstaka kurser och av enskilda lärare som sammantaget blir till en helhet som ligger i linje med universitetets rekommendationer. Läraren kan exempelvis dela upp arbetet utifrån en relationsskapande process, såsom i Figur I, för att med små medel skapa en djupare form av lärande och inkludera utveckling av generiska färdigheter som studenterna kan ta med sig i sin framtida yrkesroll. Studentaktiverande utbildningsformer och variation tillåter kreativitet och uppmuntrar till tillit till studenternas möjligheter att vara delaktiga och aktiva i deras eget lärande. Eftersom samhället och industrin är i behov av nya kunniga ingenjörer, där flera ingenjörsyrken är bristyrken i Sverige idag, och som hanterar några av dagens stora globala utmaningar är det viktigt att utbilda kunniga ingenjörer som kan samarbeta mot dessa gemensamma mål; detta kräver en balans mellan mjuka/generiska och hårda färdigheter i utbildningen. Det kan närmast ses som en moralisk skyldighet att utveckla undervisningen av ingenjörer så att utbildningarna blir tillräckligt attraktiva för att locka fler studenter till att arbeta med ingenjörslösningar av samhällsutmaningar. Många av oss som undervisar eller arbetar inom ingenjörsvetenskaperna kan bli goda förebilder för ungdomar och studenter. 


\section{Jennifer Leijon och Cecilia Boström}

Reflektion av resultatet från fallstudien är vikten av att tydliggöra för studenterna varför man förändrar ett undervisningsmoment för att skapa trygghet och för att förbereda studenterna på vilket resultat man förväntar sig av förändringen. Detta kan göras genom att hänvisa till särskilda riktlinjer eller forskning. Mer forskning kan även läggas på att undersöka studenters och lärares syn på mjuka värden inbäddade i ingenjörsvetenskapen. Vissa studenters känsla av rörighet under lektionerna kan vara en naturlig del av fler diskussioner och synliggörandet av fler personer i klassrummet, som är en del av arbetet mot utveckling av studenternas generiska färdigheter. Då fallstudien i kraftelektronik framförallt var kvantitativ och främst utifrån lärarens synsätt, så kan framtida kvalitativa studier vara värdefulla för att ge en tydligare bild av hur studenterna uppfattar en annan typ av undervisning och leda till vidare reflektion och förbättringar.

Projektets genomförande drevs av lärarens personliga vilja att göra något, stort som smått, åt den låga andelen godkända studenter och det likformigt utformade lektionsupplägget. Eftersom förändringarna är så pass små krävdes inte mer tid från lektionsledaren än den som redan var avsatt för förberedelser för undervisningen. Att försöka få en relationsskapande syn på undervisningen och genom att visa vikten av generiska färdigheter bidrar detta till normkritiskt arbete inom ingenjörsvetenskapen. Således kanske det inte handlar om vad som görs utan att något görs. Läraren måste vara modig och trygg nog i sig själv för att våga utmana de mer traditionella sätten att lägga upp räknelektioner och omgivningen bör vara uppmuntrande, tålmodig och tillåtande för att ge utrymme för förändring. Det hjälper nog att ha pedagogiska program i ryggen som en stöttepelare i att arbetet är relevant och i linje med vad universitetet eftersöker hos dess lärare.

Dagens ingenjörer behöver ha mer generiska färdigheter än tidigare och det är den högre utbildningens uppgift att hjälpa studenterna till att utveckla studenternas förmåga till exempelvis teamwork och kommunikation, utöver de goda tekniska och teoretiska kunskaperna som studenterna redan uppmuntras till vid universitetet. Allt förändringsarbete kan möta motstånd, inte minst från de studenter som förväntas utvecklas av förnyandet. Eftersom variation i undervisningen ska inkluderas för att inte entydigt gynna en och samma lärstil är det möjligt att de studenter som tidigare gynnats av denna blir negativt inställda till förändringar som syftar till att även andra studenters lärstilar och färdigheter ska uppmärksammas. På samma sätt kan förnyelsearbete i enlighet med universitetets regelverk uppröra andra lärare då arbetet kan betyda att en viss kurs behöver förändras ordentligt och byta inriktning helt, vissa moment kanske behöver strykas och andra läggas till, för att möta de nya behov som vi ser hos dagens ingenjörer och för att göra plats för exempelvis verklighetstrogna samarbetsprojekt. Här behöver universiteten ge mycket stöd till de enskilda individer som försöker utveckla ingenjörskurser eller -program för att möta dagens utmaningar mot ett hållbart samhälle och inkludera andra värderingar såsom samarbete för djupinriktat och studentaktiverat lärande. Framöver kommer den pedagogiska utvecklingen av kurser såsom Kraftelektronik att fortsätta i enlighet med universitetets pedagogiska program.

\section{SLUTSATS}

För att upprätthålla det fastställda pedagogiska programmet vid Uppsala universitet inom teknikvetenskaper samt för att arbeta i linje med rådande pedagogisk forskning och mot nya mål för framtida ingenjörer krävs förändringar av exempelvis lektionsupplägget där räkneuppgifter löses. För att skapa en kontrast till de hårda värden som kan kopplas till matematik och teknik och för att understödja utveckling av studenternas generiska färdigheter belyses de olika delarna 
av undervisningen utifrån några ord som kan kopplas till mellanmänskliga relationer och mjuka värden. Räknelektionerna i Kraftelektronik, en traditionellt tekniktung kurs och utveckling i hårda färdigheter, omarbetades utan större tidsåtgång utifrån en pedagogisk idé om relationskapande processer. Efter förändringsarbetet blev en större andel studenter godkända vid kursens ordinarie tentamen och fler studenter än året innan var ganska eller mycket nöjda med kursen vid slutlig kursvärdering, men anledningen till detta kan bero på flera olika saker. Förhoppningen är att denna reflektion ska kunna inspirera till ett förändringsarbete inom teknikvetenskaper och inkluderande av mer variation och ökad utveckling av studenternas generiska färdigheter.

Tack till övriga lärare och studenter på kursen Kraftelektronik, till kollegorna på Avdelningen för elektricitetslära samt lärare vid Högskolepedagogisk grundkurs vid Uppsala universitet. Tack även till förbättringsförslagen och granskningen från Högre utbildning innan publicering. Detta arbete är finansierat av Vetenskapsrådet (stipendienummer: 2015-03126) och STandUP for Energy.

\section{FÖRFATTARPRESENTATIONER}

Jennifer Leijon är civilingenjör i teknisk fysik och doktorand på Avdelningen för elektricitetslära, Uppsala universitet, med forskningsområdet: vågkraftsdriven avsaltning. Hon är intresserad av pedagogisk utveckling av ingenjörskurser och hur man kan att öka andelen kvinnliga elektroingenjörsstudenter.

Cecilia Boström är universitetslektor på Avdelningen för elektricitetslära vid Uppsala universitet. Hon forskar inom elsystem och förnybara energikällor, och handleder doktorander. Hon har undervisat vid flera ingenjörskurser inom elkraftteknik och är intresserad av pedagogisk utveckling.

\section{REFERENSER}

Andersson, J. A., Bernaudat, F., Bruzelius, K., Lejdfors, C., \& Nilsson, A. (2004). Att motivera förändring. In 2: a Pedagogiska Inspirationskonferensen 2004, LTH.

Angelo, T. A., \& Cross, P. K. (1993). Classroom Assessment Techniques: A Handbook for College Teachers (2nd ed.). San Francisco: Jossey-Bass.

Boyce, G., Williams, S., Kelly, A., \& Yee, H. (2001). Fostering deep and elaborative learning and generic (soft) skill development: the strategic use of case studies in accounting education. Accounting Education, 10(1), 37-60. http://doi.org/10.1080/09639280121889

Burke-Smalley, L. A., Rau, B. L., Neely, A. R., \& Evans, W. R. (2017). Factors perpetuating the research-teaching gap in management: A review and propositions. International Journal of Management Education, 15(3), 501-512. http://doi.org/10.1016/j.ijme.2017.08.004

Catarino, P., Nascimento, M. M., Morais, E., Campos, H., \& Vasco, P. (2017). Breaking the habit: engineering students' understanding of mathematical creativity. European Journal of Engineering Education, 1-12. http://doi.org/10.1080/03043797.2017.1367760

Chan, C. K. Y., Fong, E. T. Y., Luk, L. Y. Y., \& Ho, R. (2017). A review of literature on challenges in the development and implementation of generic competencies in higher education curriculum. International Journal of Educational Development, 57(June), 1-10. http://doi.org/10.1016/j. ijedudev.2017.08.010

Clive, D., Agogino, A., Eris, O., Frey, D. D., Leifer, L. J., Dym, C. L., ... Leifer, L. J. (2005). Engineering Design Thinking, Teaching, and Learning. Journal of Engineering Education, (January), 103-120. http:// doi.org/10.1109/EMR.2006.1679078

Elmgren, M., \& Henriksson, A.-S. (2016). Universitetspedagogik (3rd ed.). Lund: Studentlitteratur.

Felder, R. M., Woods, D. R., Stice, J. E., \& Rugarcia, A. (2000). The Future of Engineering Education II. Teaching Methods That Work. Chemical Engineering Education, 34(1), 26-39. http://doi. org/10.1.1.34.1082

Felgueiras, M. C., Rocha, J. S., \& Caetano, N. (2017). Engineering education towards sustainability. In Energy Procedia, 4th International Conference on Energy and Environment Research, ICEER 2017, 
17-20 July 2017, Porto, Portugal (Vol. 136, pp. 414-417). Elsevier B.V. http://doi.org/10.1016/j.egypro.2017.10.266

Fernandes, J. M., Afonso, P., Fonte, V., Alves, V., \& Ribeiro, A. N. (2017). Promoting entrepreneurship among informatics engineering students: insights from a case study. European Journal of Engineering Education, 42(1), 91-108. http://doi.org/10.1080/03043797.2016.1197891

Fogg-Rogers, L., Lewis, F., \& Edmonds, J. (2017). Paired peer learning through engineering education outreach. European Journal of Engineering Education, 42(1), 75-90. http://doi.org/10.1080/03043797.2 016.1202906

Hart, D. W. (2011). Power Electronics (Internatio). New York: McGraw-Hill Education.

Heckman, J. J., \& Kautz, T. (2012). Hard evidence on soft skills. Labour Economics, 19(4), 451-464. http:// doi.org/10.1016/j.labeco.2012.05.014

Hubbard, R. (1991). 53 Interesting Ways to Teach Mathematics. Technical and Educational Services Ltd.

Leung, A. C. K., Pour, B. H., Reynolds, Dan, \& Jerzak, S. (2017). New assessment process in an introductory undergraduate physics laboratory: an exploration on collaborative learning. Assessment \& Evaluation in Higher Education, 42(2), 169-181. http://doi.org/http://dx.doi.org/10.1080/02602938.2015.10 89977

Nair, C. S., Patil, A., \& Mertova, P. (2009). Re-engineering graduate skills - A case study. European Journal of Engineering Education, 34(2), 131-139. http://doi.org/10.1080/03043790902829281

Palali, A., van Elk, R., Bolhaar, J., \& Rud, I. (2018). Are good researchers also good teachers? The relationship between research quality and teaching quality. Economics of Education Review, 64(April), 40-49. http://doi.org/10.1016/j.econedurev.2018.03.011

Prince, M. (2004). Does active learning work? A review of the research. Journal of Engineering Education, 93(3), 223-232. http://doi.org/10.1002/j.2168-9830.2004.tb00809.x

Robles, M. M. (2012). Executive Perceptions of the Top 10 Soft Skills Needed in Today's Workplace. Business Communication Quarterly, 75(4), 453-465. http://doi.org/10.1177/1080569912460400

Ruiz-Alfonso, Z., \& León, J. (2017). Passion for math: Relationships between teachers' emphasis on class contents usefulness, motivation and grades. Contemporary Educational Psychology, 51(September), 284-292. http://doi.org/10.1016/j.cedpsych.2017.08.010

Schillinger, F. L., Vogel, S. E., Diedrich, J., \& Grabner, R. H. (2018). Math anxiety, intelligence, and performance in mathematics: Insights from the German adaptation of the Abbreviated Math Anxiety Scale (AMAS-G). Learning and Individual Differences, 61(November 2017), 109-119. http://doi. org/10.1016/j.lindif.2017.11.014

Staffas, K. (2016). Developing requisite motivation in engineering studies - A study on a master and bachelor program in electronic engineering at Uppsala University. Aalborg University.

Strobel, J., Hess, J., Pan, R., \& Wachter Morris, C. A. (2013). Empathy and care within engineering: qualitative perspectives from engineering faculty and practicing engineers. Engineering Studies, 5(2), 137-159. http://doi.org/10.1080/19378629.2013.814136

Tang, K. N. (2018). The importance of soft skills acquisition by teachers in higher education institutions. Kasetsart Journal of Social Sciences, 2-7. http://doi.org/10.1016/j.kjss.2018.01.002

Tejedor, G., Segalàs, J., \& Rosas-Casals, M. (2018). Transdisciplinarity in higher education for sustainability: How discourses are approached in engineering education. Journal of Cleaner Production, 175, 29-37. http://doi.org/10.1016/j.jclepro.2017.11.085

Tezer, M., \& Aşsksoy Yildiz, G. (2015). Engineering Students' Self-Efficacy Related To Physics Learning. Journal of Baltic Science Education, 14(3), 311-326.

Uppsala universitet. (2008). Pedagogiskt program för Uppsala universitet: Riktlinjer för pedagogisk verksambet och utveckling.

Uppsala universitet. (2010a). Riktlinjer avseende studenternas arbetsvillkor vid Uppsala universitet. Retrieved from www.uu.se/arbetsvillkor

Uppsala universitet. (2010b). Riktlinjer avseende studenternas arbetsvillkor vid Uppsala universitet.

Uppsala universitet. (2014). Handlingsplan for likabehandling av studenter 2014. 
Uppsala universitet. (2018). Pedagogiskt program for Uppsala universitet - Visioner för universitetets pedagogiska verksambet och utveckling.

van Laar, E., van Deursen, A. J. A. M., van Dijk, J. A. G. M., \& de Haan, J. (2017). The relation between 21st-century skills and digital skills: A systematic literature review. Computers in Human Behavior, 72, 577-588. http://doi.org/10.1016/j.chb.2017.03.010

Veloo, A., Nor, R., \& Khalid, R. (2015). Attitude towards Physics and Additional Mathematics Achievement towards Physics Achievement. International Education Studies, 8(3), 35-43. http://doi.org/10.5539/ ies.v8n3p35

Wahid, S. N. S., Yusof, Y., \& Razak, M. R. (2014). Math Anxiety among Students in Higher Education Level. Procedia - Social and Behavioral Sciences, 123, 232-237. http://doi.org/10.1016/j.sbspro.2014.01.1419

Wallin, P., Adawi, T., \& Gold, J. (2017). Linking teaching and research in an undergraduate course and exploring student learning experiences. European Journal of Engineering Education, 42(1), 58-74. http:// doi.org/10.1080/03043797.2016.1193125

Willis, J. M. D. (2010). Learning to love math: teaching strategies that change student attitudes and get results. Alexandria, Va.: ASCD. 